legal scholarship, judicial temper, and sense of human justice commanded respect for any cause he advocated. In addition to the two volumes already mentioned, his larger contributions to the literature of public law include: Cases on Administrative Law, Selected from Decisions of English and American Courts (1911, revised edition 1928); Das Offentliche Recht der Vereinigten Staaten von Amerika (1911); Standards of American Legislation: An Estimate of Restrictive and Constructive Factors (1917); Illegitimacy Laws of the United States (1919); and Administrative Powers over Persons and Property: A Comparative Study (1928).

Radio Program of the American Political Science Association. Under the auspices of the Association's Committee on Policy, acting in coöperation with the National Advisory Council on Radio in Education, the following program of radio talks and discussions, on the general subject of Legislatures and Legislative Problems, will be broadcast over the network of the National Broadeasting Company during the first six months of 1933:

(1) January 3, "The Legislative Prospects of 1933," William Hard, Washington, D.C. ; Bronson Cutting, United States Senator from New Mexico; Henry T. Rainey, member of Congress from the 20th Illinois district.

(2) January 10, "Prohibition," Howard Lee McBain, Columbia University.

(3) January 17, "The Congress," Robert Luce, member of Congress from the 13th Massachusetts district; Arthur Capper, United States Senator from Kansas.

(4) January 24, "Budgets," Lewis Meriam, Brookings Institution; Joseph W. Byrns, member of Congress from the 6th Tennessee district; John G. Winant, governor of New Hampshire.

(5) January 31, "The Powers of Congress," James M. Beck, member of Congress from the 1st Pennsylvania district; Jesse S. Reeves, University of Michigan.

(6) February 7, "Local Government Legislative Needs of 1933," Henry W. Toll, director of American Legislators' Association; Carl H. Chatters, director of Municipal Finance Officers' Association; Clarence E. Ridley, director of International City Managers' Association; Paul V. Betters, director of American Municipal Association.

(7) February 14, "Congressional Procedure," Frederic A. Ogg, University of Wisconsin; Earl C. Michener, member of Congress from the 2nd Michigan district.

(8) February 21, "Armaments," Admiral William Ledyard Rodgers; Roland S. Morris, University of Pennsylvania. 
(9) February 28, “Philippine Independence," J. R. Hayden, University of Michigan; Manuel Roxas, speaker of Philippine House of Representatives; Butler B. Hare, member of Congress from the 2nd South Carolina district.

(10) March 7, "Farm Relief," Benjamin F. Shambaugh, University of Iowa; and others.

(11) March 14, "What is the Matter with the State Legislatures?," Albert W. Atwood, Washington, D.C.; John A. Lapp, Chicago, Ill.

(12) March 21, "Tax Reform," Thomas H. Reed, University of Michigan; Seabury C. Mastick, member of the New York Senate; Mark Graves, New York State Budget Director.

(13) March 28, "The Lobby," James K. Pollock, University of Michigan; Edward B. Logan, budget secretary of Pennsylvania; Edward P. Costigan, United States Senator from Colorado.

(14) April 4, "Allocation of Sources of Revenue Between State and Federal Governments," William B. Belknap, president of American Legislators' Association; Simeon E. Leland, University of Chicago.

(15) April 11, "Power," Clyde L. King, University of Pennsylvania; Morris Llewellyn Cooke, Philadelphia, Pa.; and others.

(16) April 18, "Parties and Pressure Groups," Arthur Krock, New York Times; E. Pendleton Herring, Harvard University.

(17) April 25, "Unemployment Insurance," Elizabeth Brandeis, University of Wisconsin; William Trufant Foster, Newton, Mass.

(18) May 2, "The World Court," Philip C. Jessup, Columbia University ; E. M. Borchard, Yale University.

(19) May 9, "Aids to Legislation," Henry W. Toll, director of American Legislators' Association; Edwin E. Witte, Wisconsin Legislative Reference Library; DeWitt Billman, Illinois Legislative Reference Bureau.

(20) May 16, "Banking," Henry Parkman, Jr., Boston, Mass. ; Marcus Nadler, New York University.

(21) May 23, "Legislative Investigations," Gerald P. Nye, United States Senator from North Dakota; Lindsay Rogers, Columbia University.

(22) May 30, "Unemployment," Frank Bane, American Public Welfare Association; and others.

(23) June 6, "The Governor and the Legislature," Harold W. Dodds, Princeton University; William T. Gardiner, governor of Maine; Hugh Reid, member of the Virginia House of Delegates.

(24) June 13, "The Legislative Product of 1933," Thomas H. Reed, University of Michigan. 
The Committee on Civic Education by Radio wishes to call the attention of members of the Association to the reprints of radio addresses already given (as well as to be given), obtainable from the University of Chicago Press at ten cents each. The addresses contain fresh, pertinent, and popularly phrased material on topics discussed in many courses in political science. The Committee suggests their availability for outside reading purposes and as a basis for class discussion. This use may be quite independent of the radio program itself. Reprints of last spring's addresses, such as those by Holcombe on Why We Have Political Parties, by Sait on The Existing Party Alignment and The Party Convention, and by Dewey on The Place of Minor Parties in the American Scene, are quite as useful this year, and for several years to come, as at the time of their delivery. ${ }^{1}$

\section{University of Michigan.}

Thomas H. ReED.

${ }^{1}$ A complete list of these reprints, up to the first of January, is as follows: (1) Introductory Address: The Twelfth Man, John H. Finley; (2) The Significance of the Coming National Elections, William B. Munro; (3) The Significance of Our State and Local Elections, William B. Munro; (4) Primaries and the Machinery of Their Operation, Charles E. Merriam; (5) The Parties and the Issues, Arthur Krock, Julian Mason, Ruth Morgan; (6) The Campaign and Economic Planning, Stuart Chase, Virgil Jordan; (7) Issues of Foreign Policy, Charles A. Beard; (8) Issues of Domestic Poliey, Charles A. Beard; (9) Why We Have Political Parties, Arthur N. Holcombe; (10) The Existing Party Alignment, Edward M. Sait; (11) The Party Convention: Its History, Organization and Work, Edward M. Sait; (12) Results of the Republican National Convention, William Hard, Henry Suydam, Paul R. Leach; (13) The Place of Minor Parties in the American Scene, John Dewey; (14) Results of the Democratic National Convention, Paul R. Leach, William Hard; (15) Issues Between the Parties, Lindsay Rogers, Algernon Lee, F. M. Davenport; (16) Issues Above the Parties, A. R. Hatton; (17) Constructive Economy in the National Government, Louis Brownlow, Carl R. Chindblom, Katherine A. Frederic, William Hard, Henry P. Seidemann; (18) Constructive Economy in State and Local Government, Thomas H. Reed, H. W. Dodds, Luther Gulick, Joseph MeGoldriek, Dorothy Straus; (19) What Can Government Do to Prevent and Relieve Unemployment?, Robert F. Wagner, Charles A. Beard; (20) How Can Government Aid Finance and Banking?, John T. Madden, Walter F. Dodd; (21) How Can Government Provide Greater Security in Our Economic System :, Paul Mazur, A. W. Macmahon; (22) Mechanics and Maneuvers of Campaigns, A. N. Holcombe; (23) Why Vote?, Charles E. Merriam; (24) Retrenching in State and Local Expenditures, Murray Seasongood, A. R. Hatton; (25) Redrawing the Boundaries of Local Government, Thomas H. Reed, Howard P. Jones, George S. Counts ; (26) Redistributing Functions of State and Local Government, Paul W. Wager, O. Max Gardner, Harry F. Byrd; (27) Reorganizing County Government, Arthur W. Bromage, Leonard D. White, Lent D. Upson; (28) Reforming Financial Methods, Luther Gulick, Harley L. Lutz, Russell Forbes; (29) Reducing and Limiting Local Indebtedness, Carl H. Chatters, C. E. Rightor, Henry Hart; (30) Revising Our State and Local Tax System, W. F. Willoughby, William Anderson, Isidor Loeb. 